\title{
Diversity Patterns and Community Structure of the Ground-Associated Macrofauna along the Beach-Inland Transition Zone of Small Tropical Islands
}

\author{
Sebastian Steibl ${ }^{+}$(D), Robert Sigl ${ }^{+}$(D), Paul E. Bräumer, Victoria Clauß, Simon Goddemeier, Stephan Hamisch, \\ Darleen Lücker, Lisa Reiprich, Lucas Stegmann, Nora Voigt (D) and Christian Laforsch *
}

\section{check for} updates

Citation: Steibl, S.; Sigl, R.; Bräumer, P.E.; Clauß, V.; Goddemeier, S.;

Hamisch, S.; Lücker, D.; Reiprich, L.; Stegmann, L.; Voigt, N.; et al.

Diversity Patterns and Community Structure of the Ground-Associated Macrofauna along the Beach-Inland Transition Zone of Small Tropical Islands. Diversity 2021, 13, 377. https://doi.org/10.3390/d13080377

Academic Editor: Luc Legal

Received: 26 July 2021

Accepted: 12 August 2021

Published: 14 August 2021

Publisher's Note: MDPI stays neutral with regard to jurisdictional claims in published maps and institutional affiliations.

Copyright: (c) 2021 by the authors. Licensee MDPI, Basel, Switzerland. This article is an open access article distributed under the terms and conditions of the Creative Commons Attribution (CC BY) license (https:// creativecommons.org/licenses/by/ $4.0 /)$.
Department of Animal Ecology and BayCEER, University of Bayreuth, Universitaetsstr. 30, D-95440 Bayreuth, Germany; sebastian.steibl@uni-bayreuth.de (S.S.); robert.sigl@uni-bayreuth.de (R.S.); paul.e.braeumer@uni-bayreuth.de (P.E.B.); victoria.clauss@uni-bayreuth.de (V.C.); simon.goddemeier@freenet.de (S.G.); stephan.hamisch@uni-bayreuth.de (S.H.); darleen.luecker@uni-bayreuth.de (D.L.); lisa.reiprich@uni-bayreuth.de (L.R.); lucas.stegmann@gmail.com (L.S.); nora.voigt@uni-bayreuth.de (N.V.)

* Correspondence: Christian.Laforsch@uni-bayreuth.de

+ Shared first-authorship.

Abstract: Biodiversity follows distinct and observable patterns. Where two systems meet, biodiversity is often increased, due to overlapping occurrence ranges and the presence of specialized species that can tolerate the dynamic conditions of the transition zone. One of the most pronounced transition zones occurs at shores, where oceans and terrestrial habitat collide, forming the shore-inland transition zone. The relevance of this transition zone in shaping a system's community structure is particularly pronounced on small islands due to their high shore-to-inland-area ratio. However, the community structure of insular faunas along this transition zone is unknown. Here, we investigated the diversity patterns along the beach-inland transition zone of small islands and tested the hypothesis that species diversity increases toward the transition zone where beach and interior habitat meet. By measuring environmental parameters, resource availability, and ground-associated macrofauna diversity along transects running across the beach-inland transition zone, we show that a gradual change in species composition from beach to the inland exists, but neither taxa richness, diversity, nor overall abundance changed significantly. These findings offer important insights into insular community structure at the transition zone from sea to land that are relevant to better understand the dynamic and unique characteristics of insular ecosystems.

Keywords: atoll; edge effect; insular ecosystem; species richness; zonation

\section{Introduction}

Understanding the drivers for species distribution and biodiversity patterns at different spatial scales is among the fundamental goals of ecological research [1]. On a global scale, biodiversity changes with elevation and latitude [2]. The main factors shaping these global diversity gradients are temperature, habitat heterogeneity, and area, coupled with environmental stability, predictability, and productivity [3]. With some exceptions (e.g., in marine gastropods in the Southern Hemisphere [4]), these environmental factors allow for the prediction of overall species richness on large spatial scales in the terrestrial and aquatic environment [5]. On smaller spatial scales, however, a given environmental parameter does not determine the occurrence of all species in the same way. Instead, different taxa adapt and respond differently to the same environmental parameter, resulting in idiosyncratic diversity patterns [6].

Shifting from global to local scales, variations in more fine-scale environmental abiotic and biotic interactions become the predominant factors influencing species distribution and, thus, biodiversity patterns [2,5]. The fine-scale gradients determining species composition 
and diversity within ecosystems or habitats can comprise, among others, distance to a site of constant nutrient input, distance to competing conspecifics or species, chemical gradients like oxygen availability or $\mathrm{pH}$, or gradual exposure to physical factors like wind or wave action [7-10].

When these abiotic or biotic gradients change rapidly on small spatial scales, transition zones between distinct communities or habitats can occur with a unique set and combination of environmental characteristics [11,12]. These transition zones can often show patterns of increased species richness, diversity, and biomass. The increased biodiversity in transition zones can be the result of overlapping distribution ranges from species occurring on either side of the transition zone. Additionally, transition zones often harbor an additional set of species that are specifically adapted to tolerate the rapidly changing environmental gradients at the transition zone, which increases the total biodiversity in the transition zone, relative to the two adjoining habitats $[11,13,14]$.

These effects of increased diversity and species turnover in the transition zone become more pronounced when the two adjacent ecosystems are more dissimilar [15], as demonstrated, for example, in bird communities [16], tropical dung beetle species [17], or grassland arthropods [18]. The dissimilarity is thereby expressed in terms of contrasting abiotic environmental conditions, habitat quality, or vegetation structure.

Shores are among the most drastic transition zones between two highly dissimilar ecosystems (i.e., ocean and land) [19]. The most common inter- and supratidal habitats of shores are beaches, which are predominantly shaped by the ocean [20]. Beach-associated species are thereby primarily controlled by physical factors like wave climate, high salinity, or sun exposure, especially on exposed beach types, like sandy beaches [10]. However, within a short distance, the environmental conditions and habitat structure change significantly with the beginning of the first pioneering plants and increasing vegetation cover [21]. Along the shifting environmental parameters between the beach and inland system, a distinct transition zone occurs. In this beach-inland transition zone, diversity patterns of plants change significantly [22], peaking at intermediate positions [23]. Whether the same patterns along the beach-inland transition zone are also present in faunal communities has not been explicitly tested.

Understanding the faunal community structure along beach-inland transition zones is particularly important for insular ecosystems (i.e., the ecosystem on a land mass that is completely surrounded by water), as their high shore-to-inland-area ratio renders this zone a dominant component of islands, especially compared to continental shores [19]. As island beaches are also regions of high external nutrient input that can form a relevant energy source for insular consumer species [24-26], understanding the faunal community structure along their beach-inland transition zone is relevant to identify how marine nutrient inputs can propagate from the beach further inland.

Therefore, this study aimed to investigate how the ground-associated macrofauna community, resource availability in the form of seagrass and terrestrial detritus, and environmental parameters change along the beach-inland transition zone of small tropical islands. We hypothesized that species diversity, species richness, and abundance gradually increase toward the edge at which the beach and inland habitat meet. We further hypothesized that the ecological gradients change rapidly along the beach-inland transition zone. To test our hypotheses, we measured environmental parameters and ground-associated macrofauna diversity along transects running from the drift line at the beach into the island interior in $0.5 \mathrm{~m}$ intervals and tested for differences in environmental parameters and diversity indices along the gradient.

\section{Materials and Methods}

\subsection{Study Site and Site Conditions}

The field study was carried out on remote, low-lying tropical atoll islands of the Maldives in the Indian Ocean. Two uninhabited islands, Veyvah (N5.425284, E73.361301) and Dhidhdhoo (N5.376454, E73.383118) (Lhaviyani/Faadhippolhu atoll) were investigated 
(for a map of the study site refer to [27]). Sampling was performed on 13 September 2019 between 11:45 to 15:00 on Veyvah (conditions: air temperature: $32{ }^{\circ} \mathrm{C}$, wind speed: $2.4 \mathrm{~m} / \mathrm{s}$ (avg. $1 \mathrm{~min}$ ), wind direction: SSW, weather conditions: clouded, partly sunny), on 14 September 2019 between 11:15 to 16:45 on Dhidhdhoo (conditions: air temperature: $31{ }^{\circ} \mathrm{C}$, wind speed: $1.1 \mathrm{~m} / \mathrm{s}$, wind direction: SSW, weather conditions: sunny with clouds) and on 15 September 2019 between 10:30 to 12:45 on Veyvah (conditions: air temperature: $33^{\circ} \mathrm{C}$, wind speed: $0.7 \mathrm{~m} / \mathrm{s}$, wind direction: SSW, weather conditions: sunny). The field surveying was covered by the legal permit of the Atoll Marine Center field station (10-A/2000/31).

\subsection{Sampling Preparation}

Sampling on both islands was carried out on the accessible beachlines (i.e., exposed sandy beaches not covered by (mangrove) vegetation). These beachlines were mapped using GPS (Garmin GPSMAP 62st, Garmin International Inc., Olathe, KS, USA) and six transects per islands were uniformly distributed along the accessible beachline in a perpendicular orientation to the drift line. The first and last transect were always positioned at $10 \mathrm{~m}$ away from the outer edges of the mapped accessible beachline, with the four remaining transects evenly distributed along the remaining space in between. The beginning of the primary vegetation (predominantly Cyperus dubius, Launaea sarmentosa, Ipomoea spp., and Sphagneticoa trilobata) was chosen as the starting point of each transect. Starting from this point, $5.5 \mathrm{~m}$ landward and seaward were defined as one transect line. Every transect comprised a total of ten $1 \times 1 \mathrm{~m}$ plots, four positioned seaward toward the drift line, and four positioned landward in the opposite direction, each equally spaced $0.5 \mathrm{~m}$ apart and terminating with an additional inland and beach reference plot, respectively. The beach and inland reference plots did not adhere to the regular $0.5 \mathrm{~m}$ spacing and were positioned directly on the drift line and further inland under the dense interior insular vegetation, respectively (see Supplementary Figure S1 for schematic drawing of the sampling design).

\subsection{Sampling Procedure}

Sampling started from the beach reference plot toward the inland. Each plot was sampled only once following the same sampling procedure. First, a picture of each plot was taken from the top view to measure vegetation cover (Tevion DC-14, Supra, Kaiserslautern, Germany; Panasonic Lumix DMC-FT5, Panasonic, Kadoma, Japan; Galaxy A5 (2017) - SMA520F, Samsung, Seoul, South Korea). Next, the plot was scanned for organisms. To detect species that might be hidden beneath vegetation, debris, or human waste, any material obstructing the view of the observers was carefully removed while scanning for hidden or buried organisms. Species were counted and identified up to the lowest possible taxonomic level and subsequently released in their original habitat. Plot temperature was measured in the four corners and in the center by inserting a soil thermometer $1 \mathrm{~cm}$ deep into the ground and averaging the five values for each plot $\left(\mathrm{P} 300 \mathrm{~W} 0-100^{\circ} \mathrm{C} \pm 0.5^{\circ} \mathrm{C}\right.$, Dostmann electronic $\mathrm{GmbH}$, Wertheim-Reicholzheim, Germany). Detritus was collected and classified into two categories (i.e., terrestrial (leaves, branches, deadwood) and marine (seagrass, marine carrion)). The wet mass of the collected detritus per plot was weighed on site using a digital scale (NTP2K $2000 \mathrm{~g} \pm 0.1 \mathrm{~g}$, Nohlex GmbH, Buchholz, Germany). Percentage of grass/herb and shrub coverage per plot was measured using ImageJ 1.49b (Rasband, W.S., ImageJ, U.S. National Institutes of Health, Bethesda, MD, USA, http:/ /imagej.nih.gov/ij/, 1997-2015, accessed on 1 October 2019).

\subsection{Statistical Analysis}

Statistical analysis was carried out using R 3.5.3 extended with the "vegan" and "hillR" packages for multivariate data analysis and calculation of Hill numbers, respectively [28-30]. The measured environmental parameters (i.e., soil surface temperature, marine detritus, terrestrial detritus, grass/herb coverage, shrub coverage) were compared between the two investigated islands using permutational multivariate analysis of variance 
(PERMANOVA) with Bray-Curtis dissimilarity indices and 4999 permutations. For each island, the environmental parameters of the beach-inland transition zone were analyzed using principal component analysis (PCA). The first three principal components (PCs) explained $70.07 \%$ of the total inertia and were used for subsequent statistical testing. One-way analysis of variances (ANOVAs) with Tukey HSD post-hoc testing and Bonferroni $p$-value correction were performed to statistically compare the first three principal components (PC1 to PC3). Taxa richness (Hill number $q=0$ ), exponential Shannon-Wiener (Hill number $q=1$ ), the inverse of Simpson's concentration index (Hill number $q=2$ ), Berger-Parker index (Hill number $q=3$ ), and total number of individuals were calculated for each plot of the transect line ( $N=6$ per island). The different values for the parameter $q$ of the Hill number quantifies how much rare species are discounted in the calculation of the diversity index. A hill number with $q=0$ is simply the number of species, while $q=1$ weighs species in proportion to their frequency. Hill numbers with $q=2$ and $q=3$ add more weight on the more abundant species, while discounting rare ones [31]. Higher values for the $q=3$ Hill number (Berger-Parker index) thus indicate that the most common species dominate (i.e., a lower evenness). The diversity indices were statistically compared between the transects of each island using the non-parametric Kruskal-Wallis test with Bonferroni $p$-value correction for multiple testing, as data did not meet the assumptions for parametric testing. For each taxon, the average occurrence range (i.e., distribution maximum \pm standard variation) along the beach-inland transition zone was obtained from the mean taxa's abundances for each plot of the transect $(N=6$ for each island). Differences in average occurrence ranges were statistically compared between the two islands using Monte Carlo-simulations (100,000 runs) and Bonferroni $p$-value corrections.

\section{Results}

Overall, the environmental parameters along the beach-inland transition zones differed significantly between the two investigated islands (PERMANOVA: $\mathrm{F}=6.537, \mathrm{df}=1$, $p=0.0016$ ). Consequently, the two islands were treated separately for all subsequent statistical analysis. Scores in PC1 correlated negatively with soil temperature, amount of standing stock of terrestrial detritus per $\mathrm{m}^{2}$, and grass/herb coverage. Within the beach-inland transition zone of each island, the PC1 scores differed significantly between the plots on Dhidhdhoo (one-way ANOVA: $\mathrm{F}=24.840$, $\mathrm{df}=9, p<0.001$ ) and on Veyvah $(\mathrm{F}=4.637$, $\mathrm{df}=9, p<0.001$; for loadings of the PCs and pairwise comparisons see Table 1 and Figure 1). Scores in PC2 correlated negatively with grass/herb coverage and positively with shrub coverage. PC2 scores did not differ significantly between the plots on Dhidhdhoo $(\mathrm{F}=0.443$, $\mathrm{df}=9, p=0.904)$ and on Veyvah $(\mathrm{F}=1.93, \mathrm{df}=9, p=0.072$; Figure 1B). Scores in PC3 correlated positively with the amount of seagrass standing stock per $\mathrm{m}^{2}$. PC3 scores differed significantly between the plots on Dhidhdhoo $(\mathrm{F}=3.382, \mathrm{df}=9, p=0.003)$, but not between the plots on Veyvah $(\mathrm{F}=0.634, \mathrm{df}=9, p=0.762$; Figure $1 \mathrm{C})$.

Table 1. Loadings of the PCA analysis for the environmental parameters. Bold values indicate major contributions of an environmental parameter to the principal component. The first three PCs explained in total $70.07 \%$ of the total inertia.

\begin{tabular}{cccc}
\hline Environmental Parameters & PC1 & PC2 & PC3 \\
\hline Explained variance & $26.86 \%$ & $22.29 \%$ & $20.92 \%$ \\
Temperature & $\mathbf{- 0 . 7 0 1}$ & -0.133 & 0.410 \\
Marine detritus & 0.261 & 0.022 & $\mathbf{0 . 9 0 4}$ \\
Terrestrial detritus & $-\mathbf{0 . 6 0 5}$ & 0.368 & 0.128 \\
Grass/ herb coverage & $\mathbf{- 0 . 5 7 6}$ & $\mathbf{- 0 . 6 0 8}$ & -0.160 \\
Shrub coverage & -0.288 & $\mathbf{0 . 7 6 9}$ & -0.122 \\
\hline
\end{tabular}





Figure 1. Principal components scores along the beach-inland transition zone. Boxplot representation for the mean PC1-PC3 scores of the beach-inland transition zones. Br: Beach reference plot; P1-P8: plot 1 to plot 8, with the first pioneering plants of the supralittoral vegetation starting between plot 4 and plot 5; Ir: Inland reference plot) of the two investigated islands (black: Dhidhdhoo, orange: Veyvah; $N=6$ per island). For the loadings of the PCs, refer to Table 1. Significant differences in the PC scores of the plots of the two islands were detected for PC1-Dhidhdhoo $(p<0.001)$ and Veyvah $(p<0.001)$ and PC3 - Dhidhdhoo $(p=0.003)$. Different letters indicate significant differences $(p<0.05)$ in the pairwise comparisons of the single plots (Tukey HSD post-hoc testing), same letters indicate no significant difference in PC score $(p>0.05)$.

Taxa richness (Hill number $q=0$ ) along the beach-inland transition zone neither differed significantly between the two investigated islands $\left(\mathrm{X}^{2}=0.978, \mathrm{df}=1, p=1.000\right)$ nor between the plots of the transects on Dhidhdhoo $\left(X^{2}=11.666, \mathrm{df}=9, p=1.000\right)$ and Veyvah $\left(X^{2}=22.185, \mathrm{df}=9, p=0.125\right.$; Figure 2A). Exponential Shannon-Wiener $H^{\prime}$ (Hill number $q=1)$ neither differed significantly between the two investigated islands $\left(X^{2}=0.035, \mathrm{df}=1\right.$, $p=1.000)$, nor between the plots of the transects on Dhidhdhoo $\left(\mathrm{X}^{2}=7.865, \mathrm{df}=9, p=1.000\right)$ and Veyvah $\left(\mathrm{X}^{2}=20.481, \mathrm{df}=9, p=0.228\right.$; Figure $\left.2 \mathrm{~B}\right)$. The inverse Simpson Index (Hill number $q=2)$ neither differed significantly between the two investigated islands $\left(\mathrm{X}^{2}=\right.$ $2.433, \mathrm{df}=1, p=1.000)$ nor between the plots of the transects on Dhidhdhoo $\left(\mathrm{X}^{2}=7.104\right.$, $\mathrm{df}=9, p=1)$ and Veyvah $\left(\mathrm{X}^{2}=15.949, \mathrm{df}=9, p=1.000\right.$; Figure 2C). The Berger-Parker index (Hill number $q=3$ ) neither differed significantly between the two investigated islands $\left(X^{2}\right.$ $=2.978, \mathrm{df}=1, p=1.000)$, nor between the plots of the transects on Dhidhdhoo $\left(\mathrm{X}^{2}=6.735\right.$, $\mathrm{df}=9, p=1.000)$ and Veyvah $\left(\mathrm{X}^{2}=15.708, \mathrm{df}=9, p=1.000\right.$; Figure 2D). The total number of individuals per plot neither differed significantly between the two investigated islands $\left(X^{2}\right.$ $=5.720, \mathrm{df}=1, p=0252)$, nor between the plots of the transects of Dhidhdhoo $\left(X^{2}=16.024\right.$, $\mathrm{df}=9, p=0.998)$ and Veyvah $\left(\mathrm{X}^{2}=21.296, \mathrm{df}=1, p=0.171\right.$; Figure 2E $)$. 


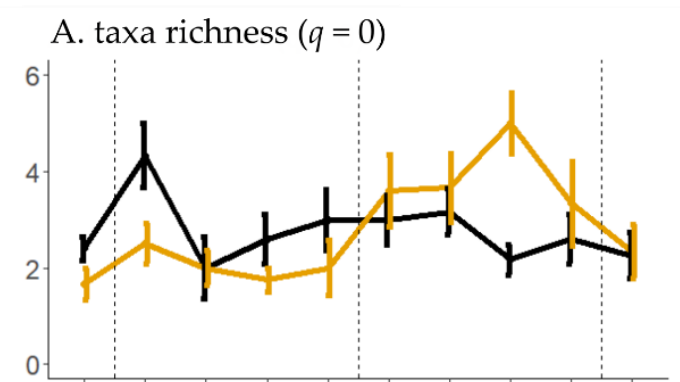

B. exponential Shannon-Wiener $(q=1)$

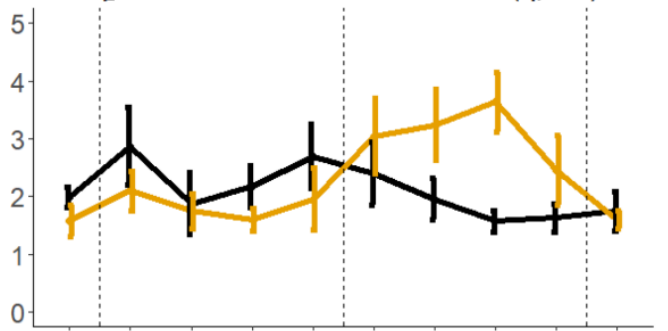

C. inverse Simpson $(q=2)$

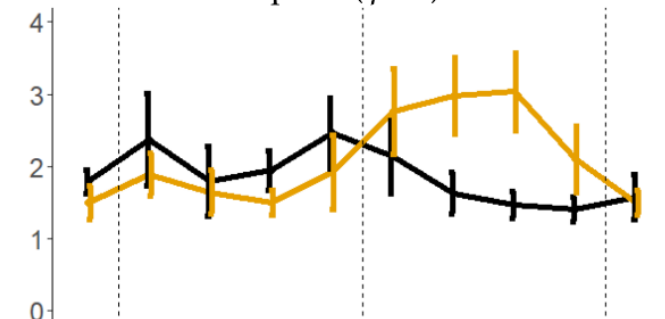

D. Berger-Parker index $(q=3)$
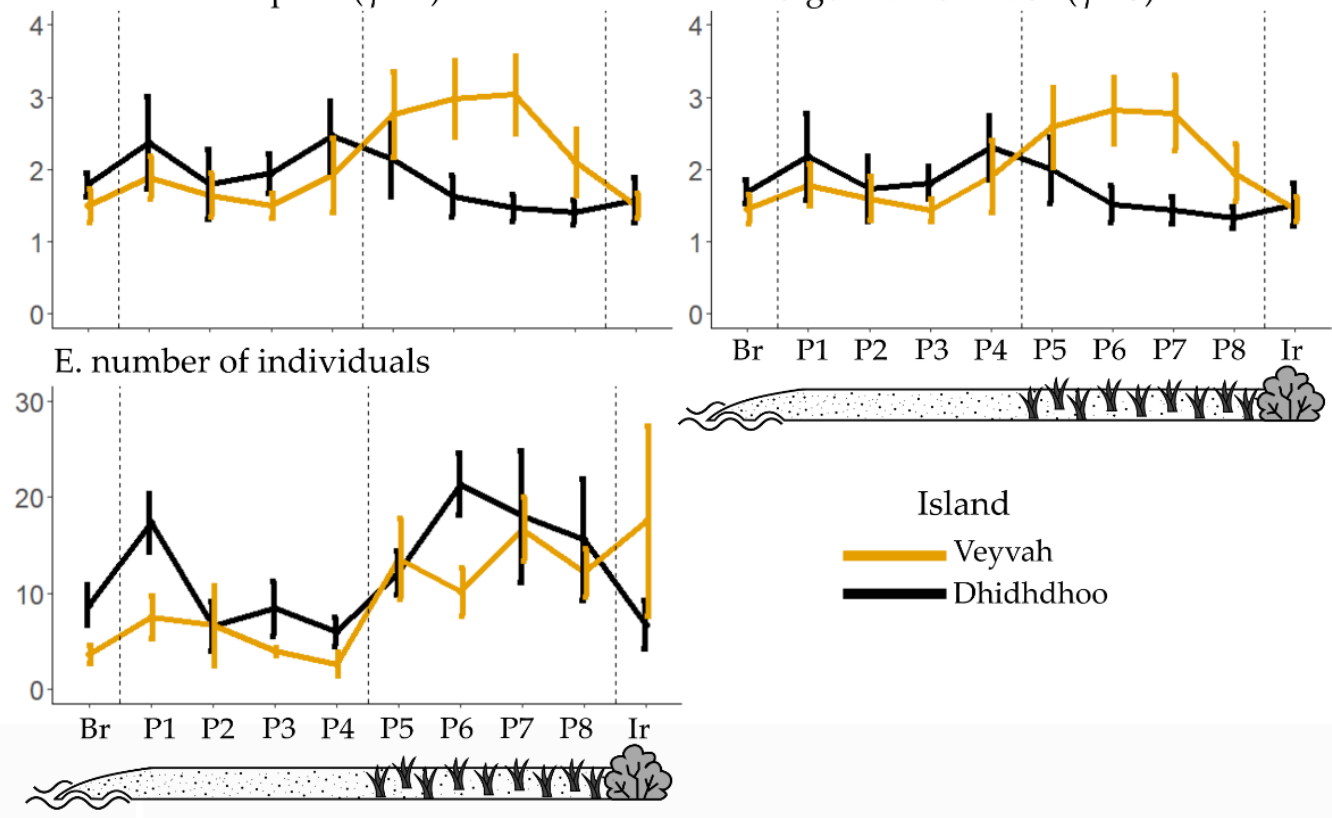

Island

- Veyvah

Dhidhdhoo

Figure 2. Change in the biodiversity parameters along the beach-inland transition zone. For each plot along the beachinland transition zone (Br: Beach reference plot; P1-P8: plot 1 to plot 8, with the first pioneering plants of the supralittoral vegetation starting between plot 4 and plot 5; Ir: Inland reference plot), the mean \pm standard error of the four biodiversity parameters (based on Hill number $q=0, q=1, q=2$, and $q=3$ ) and of the total number of individuals are presented ( $N=6$ per island). The two colors indicate the two different islands (black: Dhidhdhoo, orange: Veyvah). (A) Number of taxa per plot, (B) Exponential Shannon-Wiener $H^{\prime}$, puts species richness in proportion to their abundance. (C) Inverse Simpson, gives abundant species more weight and discounts for rarer ones. (D) Berger-Parker index, weighs also for more abundant species. (E) Total number of individuals per plot. None of the calculated diversity indices differed significantly between the two islands (Kruskal-Wallis: $p>0.05)$ or between the different plots within each island $(p>0.05)$.

The calculated mean occurrences of the species along the beach-inland transition zone (Figure 3) did not differ significantly between the two investigated islands (Monte Carlo simulation: $p>0.05$ for all comparisons). The summarized taxa richness into phylogenetic groups (crustaceans, insects, spiders, other, i.e., one chilopod, one reptile, one pseudoscorpion taxa) changed from predominantly crustaceans in the beach habitat to insect- and spider-dominated in the supralittoral vegetated inland habitat (Figure 4). 


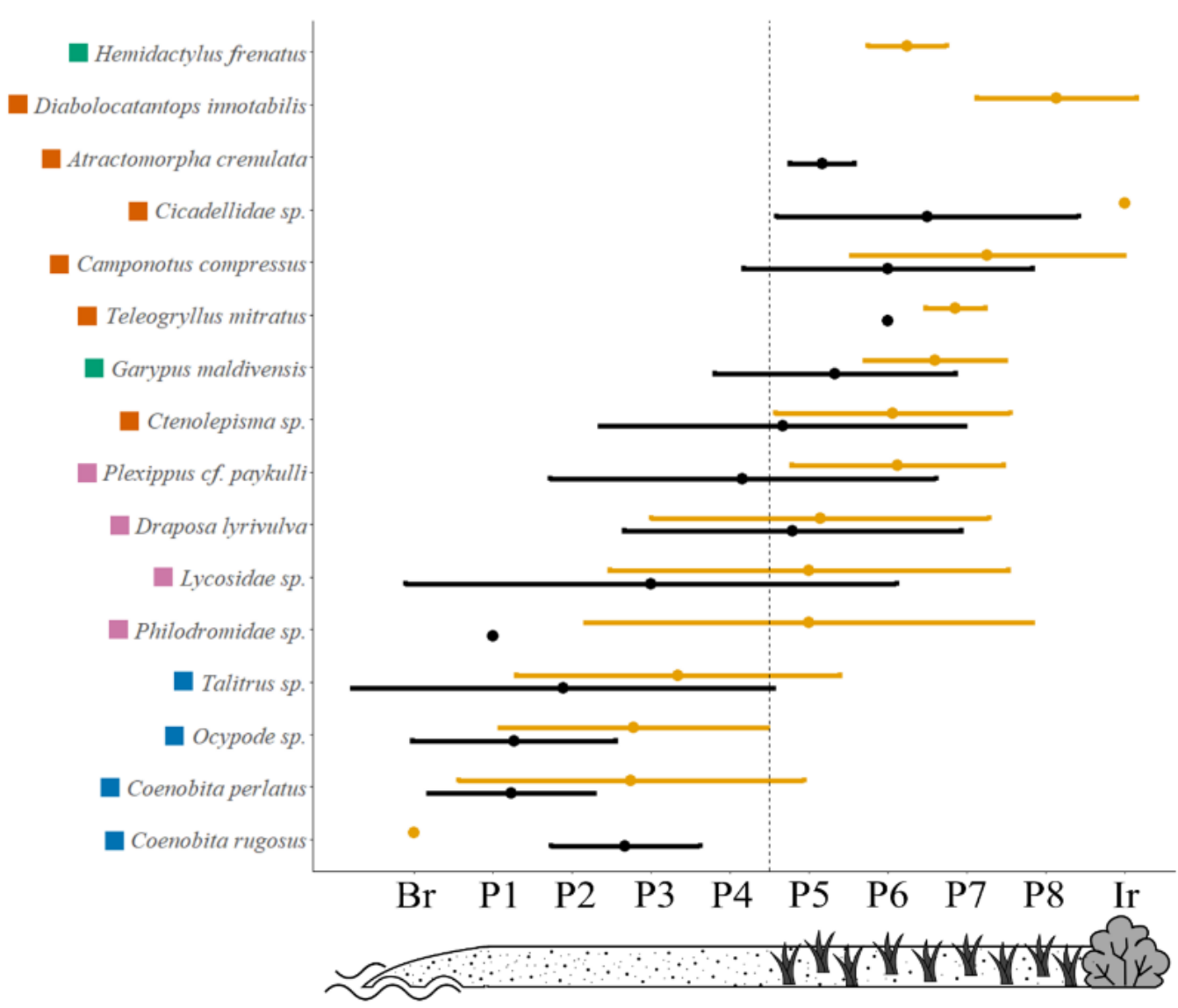

Figure 3. Mean occurrence range of the macrofauna in the beach-inland transition zone. Circles indicate the mean occurrence maximum for each taxon, error bars the occurrence range (i.e., mean \pm standard deviation; $N=6$ per island) at the beach-inland transition zone (Br: Beach reference plot; P1-P8: plot 1 to plot 8, with the first pioneering plants of the supralittoral vegetation starting between plot 4 and plot 5 , indicated by the dashed vertical line; Ir: Inland reference plot). The five taxa that were sampled only once during the field sampling were excluded from this analysis and graphical representation. The coloration of the plotted bars indicates the two different islands (black: Dhidhdhoo, orange: Veyvah). The colors before the species names indicate the broader taxonomic grouping (blue: crustaceans, brown: insects, purple: spiders, green: other, see also Figure 4). 


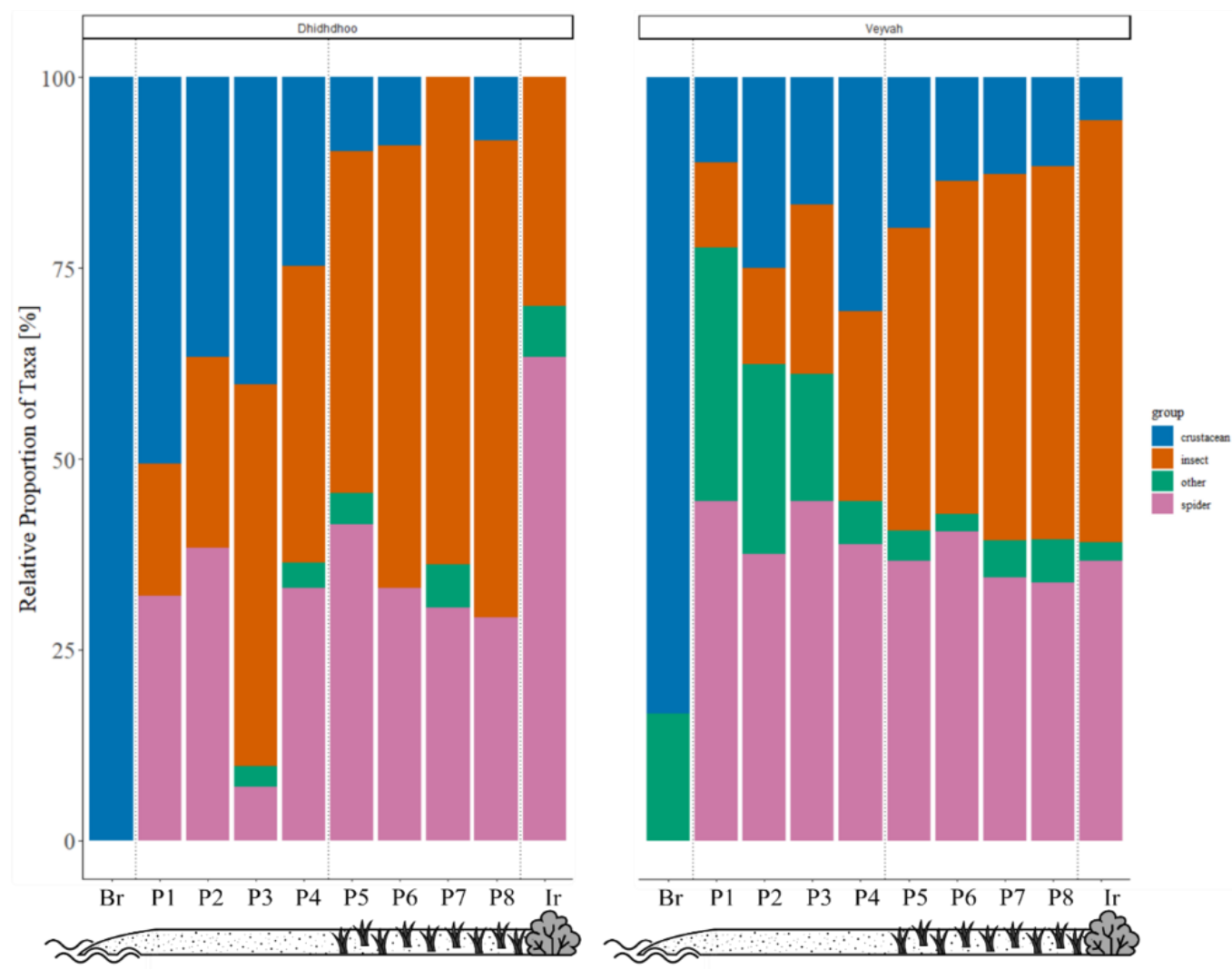

Figure 4. Relative proportion of phylogenetic groups to the overall taxa richness along beach-inland transition zone. The deconstructed mean taxa richness into phylogenetic groups (blue: crustaceans, brown: insects, purple: spiders, green: other) along the beach-inland transition zone (Br: Beach reference plot; P1-P8: plot 1 to plot 8, with the first pioneering plants of the supralittoral vegetation starting between plot 4 and plot 5, indicated by the dashed vertical line; Ir: Inland reference plot) changed from crustacean-dominated close to the drift line to insect- and spider-dominated in the supralittoral vegetation on Dhidhdhoo (left) and Veyvah (right; $N=6$ ).

\section{Discussion}

This study investigated the environmental parameters and the diversity pattern of the ground-associated macrofauna community along the beach-inland transition zone of small and remote tropical atoll islands. We show that the environmental parameters gradually changed from beach to inland. Along this environmental gradient, different ground-associated species occupy different sections with a smooth trend for increasing terrestriality in the type of fauna present (i.e., more insect and spider taxa, fewer crustaceans when shifting along the transition zone from beach to insular interior) as the environmental conditions become less shaped by the harsh beach conditions.

Generally, both islands matched the conditions of reflective microtidal beaches [32,33]. Even though one island (Dhidhdhoo) showed a rapid change (i.e., significant changes in environmental parameters within $0.5 \mathrm{~m}$ ) at the area of the first pioneer plants in the transition zone and the second island (Veyvah) displayed a more gentle gradient, the general patterns of the environmental gradients were similar on both atoll islands [34]. Terrestrial detritus, which forms the dietary basis for most taxa on the inland, on islands with sufficient in situ primary production [24], along with soil temperature and vegetation coverage increased from the beach to the inland on both islands, displaying the expected patterns also known from continental beach systems [35,36]. The amount of available marine detritus, which forms the dietary basis for most beach-dwelling taxa [37], was generally higher on the beach on Veyvah. In contrast, on Dhidhdhoo, it peaked at the edge toward the inland habitat where the first pioneer plants appear (Figure 1C). Here, pioneering supralittoral vegetation at the upper margin of the beach might act as a barrier 
holding back seagrass and other marine detritus that gets washed ashore during high tide or storm events, resulting in its highest availability not directly at the drift line, but at the margin of the inland habitat [38].

Despite the apparent gradient in environmental conditions from the drift line at the beach across the beach-inland transition zone and into the interior insular vegetation, the ground-associated fauna's overall richness, abundance, and diversity did not change significantly across the investigated transition zone on a species/genus level. However, summarizing the overall species distribution into larger taxonomic groups revealed that the ground-associated macrofauna community is changing completely along the beach-inland transition zone, albeit the diversity indices did not change significantly (Figures 3 and 4). This species turnover is in line with earlier findings that showed comparable turns in community composition in other highly dissimilar adjoining ecosystems [16,17].

Crustaceans (Coenobita spp., Ocypode sp., Pachygrapsus minutus, Talitrus sp.) dominated the beach environment and rarely-if at all-were observed dispersing over the margin of the beach across the transition zone into the vegetated supralittoral habitat. The gradually increasing soil temperature, which also indicates decreased soil moisture and salinity $[36,39]$, toward the upper margin of the beach and the beach-inland transition zone likely forms a natural dispersal barrier for the beach-associated crustacean taxa, which depend on, for example, fine-grained, moist soil for burrowing [27,40]. Although terrestrial hermit crabs, Coenobita spp., are known to disperse further landward into densely vegetated mangrove or forest habitats [41-43], these results indicate that they do not reside in large numbers in the sparsely vegetated beach-inland transition zone, at least during the day, probably to avoid desiccation [44]. On the other hand, hexapods and their common predator, the house gecko Hemidactylus frenatus, were recorded rarely-if at all-on the beach side of the transition zone. Their natural dispersal range seaward might be limited by available supralittoral vegetation, which offers a heterogeneous microenvironment and serves as a shelter, and food and nutrient supply [45]. The absence of primary production and terrestrial detritus further seaward might additionally deter the herbivorous and detritivorous taxa from dispersing further into the beach side of the transition zone beyond the line of first pioneering plants [46]. This bipartite distribution pattern of crustaceans (beach) and hexapods (inland), following their natural dispersal limits along the beach-inland transition zone, would also partly explain why energy fluxes between beach and inland communities on small islands with sufficient primary production are limited [24].

Although the dispersal ranges of crustaceans and hexapods only marginally overlapped around the beach-inland transition zone, a third group of taxa was found on both sides of the transition zone: non-web-building spiders (Lycosidae, Philodromidae, Salticidae). Since vegetation structure and prey availability determine the distribution of spiders [47], it is likely that the observed wolf-, jumping-, and running-spider taxa are all adapted specifically to sparse vegetation structure, like as occurred along the beachinland transition zone in the studied system [48]. Jumping-, wolf-, and running-spiders can be fairly thermotolerant [48], allowing them to withstand the dynamic environmental conditions at the beach-inland transition zone. They are not dependent on vegetation as they do not build webs for hunting prey [47] and thus can advance further into the beach environment for foraging than other predators $[49,50]$. Therefore, other than the initial hypothesis, the beach-inland transition zone of small tropical islands is not an area of elevated species diversity where beach and inland taxa overlap, but instead, is primarily occupied by non-web building spiders. Their occurrence between the beach and inland fauna results in the observed consistent total taxa richness when shifting across the beach-inland transition zone on the investigated small tropical insular system.

A noteworthy feature of the observed biodiversity patterns across the beach-inland transition zone is the remoteness of the investigated system, the Maldivian archipelago in the Indo-Pacific. Many studies in various continental systems identified transition zones as regions with increased biodiversity due to overlapping distribution ranges of species and additional specialists that are adapted to tolerate the rapidly changing environmental 
gradients [11,12]. This pattern could not be observed in the present system. The overall remoteness of the Maldivian islands coupled with their small island sizes allows only a limited number of taxa to reach and successfully colonize these islands [51-53]. Furthermore, the absence of any transition-zone-specialists could be caused by the highly dynamic character of these small atoll islands, which display constant changes in their insular morphology $[54,55]$. When systems are dynamic in space and time, transition zones and ecosystem boundaries become less diverse with fewer specifically adapted taxa present than in more stable ecosystems [56]. Additionally, due to the Maldivian islands' overall young geological age (although the archipelago itself is about 55 million years old, the present Maldivian islands started forming ca. 3000 years ago after being fully submersed during the last glacial period), processes of speciation and adaptive radiation to tolerate the environmental conditions of the beach-inland transition zone might have not (yet) taken place. These factors probably result in a paucity of endemic and specialist taxa in the beach-inland transition zone of the investigated remote atoll islands compared to continental systems $[54,57]$. Taking the factors above together could explain why neither a highly diverse beach and inland fauna, nor any changes in taxa richness or abundance along the transition zone were observed. Instead, an overall low but consistent taxa richness across the beach-inland transition zone in the investigated system was recorded, albeit the macrofauna community composition changed completely along the transition zone.

\section{Conclusions}

The present study shows how taxa richness and diversity of the ground-associated macrofauna on remote tropical atoll islands in the Indo-Pacific are structured along the environmental gradients of the beach-inland transition zone. While the relevant environmental gradients that determine the biodiversity patterns of the beach and supralittoral communities have already been investigated on global to regional scales [58], this study demonstrated how the biodiversity of the beach and supralittoral macrofauna is structured on a small spatial scale. In light of globally accelerating habitat conversion, especially drastic in the coastal environment [59], these findings also provide new and relevant insights into community dynamics and diversity patterns of the coastal- and supralittoral-associated macrofauna.

Supplementary Materials: The following supplementary figures are available online at https:// www.mdpi.com/article/10.3390/d13080377/s1, Figure S1: Scheme of sampling transects and plots.

Author Contributions: Conceptualization, S.S., R.S. and C.L.; Methodology, S.S., R.S., and C.L.; Validation, S.S., R.S. and C.L.; Formal analysis, S.S.; Investigation, S.S., R.S., P.E.B., V.C., S.G., S.H., D.L., L.R., L.S., N.V. and C.L.; Resources, C.L.; Data curation, S.S.; Writing-original draft preparation, S.S., R.S., P.E.B., V.C., S.G., S.H., D.L., L.R., L.S., N.V. and C.L.; Writing-review and editing, S.S., R.S. and C.L.; Visualization, S.S.; Supervision, S.S., R.S. and C.L.; Project administration, S.S., R.S. and C.L. All authors have read and agreed to the published version of the manuscript.

Funding: This research received no external funding.

Institutional Review Board Statement: Not applicable.

Data Availability Statement: All raw data and statistical code can be accessed via the Dryad Digital Repository, https://doi.org/10.5061/dryad.qbzkh18gr, accessed on 11 August 2021.

Acknowledgments: We thank the NGOs "Naifaru Juvenile" and "Atoll Marine Centre" (Lh. Naifaru, Lhaviyani Atoll, Republic of Maldives) for providing accommodation and infrastructure during the field sampling. Financial support for Sebastian Steibl and Stephan Hamisch by the "Studienstiftung des deutschen Volkes" scholarship is gratefully acknowledged.

Conflicts of Interest: The authors declare no conflict of interest. 


\section{References}

1. Sutherland, W.J.; Freckleton, R.P.; Godfray, H.C.J.; Beissinger, S.R.; Benton, T.; Cameron, D.D.; Carmel, Y.; Coomes, D.A.; Coulson, T.; Emmerson, M.C.; et al. Identification of 100 fundamental ecological questions. J. Ecol. 2013, 101, 58-67. [CrossRef]

2. Willis, K.J.; Whittaker, R.J. Species diversity-Scale matters. Science 2002, 295, 1245-1248. [CrossRef]

3. Rohde, K. Latitudinal gradients in species diversity and Rapoport's rule revisited: A review of recent work and what can parasites teach us about the causes of the gradients? Ecography 1999, 22, 593-613. [CrossRef]

4. Valdovinos, C.; Navarrete, S.A.; Marquet, P.A. Mollusk species diversity in the Southeastern Pacific: Why are there more species towards the pole? Ecography 2003, 26, 139-144. [CrossRef]

5. Whittaker, R.J.; Willis, K.J.; Field, R. Scale and species richness: Towards a general, hierarchical theory of species diversity. J. Biogeogr. 2001, 28, 453-470. [CrossRef]

6. Astorga, A.; Fernández, M.; Boschi, E.E.; Lagos, N. Two oceans, two taxa and one mode of development: Latitudinal diversity patterns of South American crabs and test for possible causal processes. Ecol. Lett. 2003, 6, 420-427. [CrossRef]

7. Mittelbach, G.G.; Steiner, C.F.; Scheiner, S.M.; Gross, K.L.; Reynolds, H.L.; Waide, R.B.; Willig, M.R.; Dodson, S.I.; Gough, L. What is the observed relationship between species richness and productivity? Ecology 2001, 82, 2381-2396. [CrossRef]

8. Terborgh, J.; Weske, J.S. The role of ecotones in the distribution of Andean birds. Ecology 1975, 56, 562-576. [CrossRef]

9. Armonies, W.; Reise, K. Faunal diversity across a sandy shore. Mar. Ecol. Prog. Ser. 2000, 196, 49-57. [CrossRef]

10. McLachlan, A.; Jaramillo, E.; Donn, T.E.; Wessels, F. Sandy beach macrofauna communities and their control by the physical environment: A geographical comparison. J. Coast. Res. 1993, 15, 27-38. [CrossRef]

11. Kark, S. Ecotones and ecological gradients. In Ecological Systems: Selected Entries from the Encyclopedia of Sustainability Science and Technology; Leemans, R., Ed.; Springer Science \& Business Media: New York, NY, USA, 2013; pp. 147-160. ISBN 9781441908513.

12. Kark, S.; van Rensburg, B.J. Ecotones: Marginal or central areas of transition? Isr. J. Ecol. Evol. 2006, 52, 29-53. [CrossRef]

13. Schilthuizen, M. Ecotone: Speciation-prone. Trends Ecol. Evol. 2000, 15, 130-131. [CrossRef]

14. Kolasa, J.; Zalewski, M. Notes on ecotone attributes and functions. Importance Aquat. Ecotones Freshw. Fish 1995, 303, 1-7. [CrossRef]

15. Angelstam, P. Predation on ground-nesting birds' nests in relation to predator densities and habitat edge. Oikos 1986, 47, 365-373. [CrossRef]

16. Reino, L.; Beja, P.; Osborne, P.E.; Morgado, R.; Fabião, A.; Rotenberry, J.T. Distance to edges, edge contrast and landscape fragmentation: Interactions affecting farmland birds around forest plantations. Biol. Conserv. 2009, 142, 824-838. [CrossRef]

17. Peyras, M.; Vespa, N.I.; Bellocq, M.I.; Zurita, G.A. Quantifying edge effects: The role of habitat contrast and species specialization. J. Insect Conserv. 2013, 17, 807-820. [CrossRef]

18. Yekwayo, I.; Pryke, J.S.; Roets, F.; Samways, M.J. Responses of ground living arthropods to landscape contrast and context in a forest-grassland mosaic. Biodivers. Conserv. 2017, 26, 631-651. [CrossRef]

19. Gillis, J.R. Not continents in miniature: Islands as ecotones. Isl. Stud. J. 2014, 9, 155-166.

20. McLachlan, A. Coastal beach ecosystems. Encycl. Biodivers. 2001, 1, 741-751. [CrossRef]

21. Fenu, G.; Carboni, M.; Acosta, A.T.R.; Bacchetta, G. Environmental factors influencing coastal vegetation pattern: New insights from the Mediterranean basin. Folia Geobot. 2013, 48, 493-508. [CrossRef]

22. Torca, M.; Campos, J.A.; Herrera, M. Changes in plant diversity patterns along dune zonation in south Atlantic European coasts. Estuar. Coast. Shelf Sci. 2019, 218, 39-47. [CrossRef]

23. Fenu, G.; Cogoni, D.; Ferrara, C.; Pinna, M.S.; Bacchetta, G. Relationships between coastal sand dune properties and plant community distribution: The case of Is Arenas (Sardinia). Plant Biosyst. 2012, 146, 586-602. [CrossRef]

24. Paetzold, A.; Lee, M.; Post, D.M. Marine resource flows to terrestrial arthropod predators on a temperate island: The role of subsidies between systems of similar productivity. Oecologia 2008, 157, 653-659. [CrossRef] [PubMed]

25. Ince, R.; Hyndes, G.A.; Lavery, P.S.; Vanderklift, M.A. Marine macrophytes directly enhance abundances of sandy beach fauna through provision of food and habitat. Estuar. Coast. Shelf Sci. 2007, 74, 77-86. [CrossRef]

26. Polis, G.A.; Hurd, S.D. Linking marine and terrestrial food webs: Allochthonous input from the ocean supports high secondary productivity on small islands and coastal land communities. Am. Nat. 1996, 147, 396-423. [CrossRef]

27. Steibl, S.; Laforsch, C. Compartmentalized organization of ecological niche occupation in insular invertebrate communities. Ecol. Evol. 2021, 11, 471-480. [CrossRef]

28. Oksanen, J. Multivariate analysis of ecological communities in R: Vegan tutorial. R Package Version 2011, 1, 1-43. [CrossRef]

29. Team, R.C. R: A Language and Environment for Statistical Computing; R Foundation for Statistical Computing: Vienna, Austria, 2018.

30. Li, D. hillR: Taxonomic, functional, and phylogenetic diversity and similarity through Hill Numbers. J. Open Source Softw. 2018, 3 , 1041. [CrossRef]

31. Chao, A.; Gotelli, N.J.; Hsieh, T.C.; Sander, E.L.; Ma, K.H.; Colwell, R.K.; Ellison, A.M. Rarefaction and extrapolation with Hill numbers: A framework for sampling and estimation in species diversity studies. Ecol. Monogr. 2014, 84, 45-67. [CrossRef]

32. McArdle, S.B.; McLachlan, A. Sand beach ecology: Swash features relevant to the macrofauna. J. Coast. Res. $1992,8,398-407$.

33. Defeo, O.; McLachlan, A. Patterns, processes and regulatory mechanisms in sandy beach macrofauna: A multi-scale analysis. Mar. Ecol. Prog. Ser. 2005, 295, 1-20. [CrossRef]

34. Woodroffe, C.D. Reef-island topography and the vulnerability of atolls to sea-level rise. Glob. Planet. Chang. 2008, 62, 77-96. [CrossRef] 
35. Colombini, I.; Chelazzi, L. Influence of marine allochthonous input on sandy beach communities. Oceanogr. Mar. Biol. Annu. Rev. 2003, 41, 115-159.

36. Harrison, S.J.; Morrison, P. Temperatures in a sandy beach under strong solar heating: Patara beach, Turkey. Estuar. Coast. Shelf Sci. 1993, 37, 89-97. [CrossRef]

37. Dugan, J.E.; Hubbard, D.M.; McCrary, M.D.; Pierson, M.O. The response of macrofauna communities and shorebirds to macrophyte wrack subsidies on exposed sandy beaches of southern California. Estuar. Coast. Shelf Sci. 2003, 58, 25-40. [CrossRef]

38. Feagin, R.A.; Furman, M.; Salgado, K.; Martinez, M.L.; Innocenti, R.A.; Eubanks, K.; Figlus, J.; Huff, T.P.; Sigren, J.; Silva, R. The role of beach and sand dune vegetation in mediating wave run up erosion. Estuar. Coast. Shelf Sci. 2019, 219, 97-106. [CrossRef]

39. Barboza, F.R.; Gómez, J.; Lercari, D.; Defeo, O. Disentangling diversity patterns in sandy beaches along environmental gradients. PLoS ONE 2012, 7, e40468. [CrossRef]

40. Scapini, F. Behaviour of mobile macrofauna is a key factor in beach ecology as response to rapid environmental changes. Estuar. Coast. Shelf Sci. 2014, 150, 36-44. [CrossRef]

41. Page, H.M.; Willason, S.W. Distribution patterns of terrestrial hermit crabs at Enewetak Atoll, Marshall Islands. Pac. Sci. 1982, 36, 107-117.

42. Hamasaki, K.; Fujikawa, S.; Sanda, T.; Tsuru, T.; Kitada, S. Distributions of land hermit crabs (Decapoda: Coenobitidae) on the coast of the tidal lagoon, Nagura Amparu, on Ishigakijima Island, Japan. Biogeography 2017, 19, 142-149.

43. Barnes, R.S.K.; Smith, D.J.; Barnes, D.K.A.; Gerlach, J. Variation in the distribution of supralittoral vegetation around an atoll cay: Desroches (Amirante Islands, Seychelles). Atoll Res. Bull. 2008, 565, 1-6. [CrossRef]

44. Steibl, S.; Laforsch, C. Daytime activity and habitat preferences of two sympatric hermit crab species (Decapoda: Anomura: Coenobita). Estuar. Coast. Shelf Sci. 2019, 231, 106482. [CrossRef]

45. Romanuk, T.N.; Levings, C.D. Associations between arthropods and the supralittoral ecotone: Dependence of aquatic and terrestrial taxa on riparian vegetation. Environ. Entomol. 2003, 32, 1343-1353. [CrossRef]

46. Colombini, I.; Brilli, M.; Fallaci, M.; Gagnarli, E.; Chelazzi, L. Food webs of a sandy beach macroinvertebrate community using stable isotopes analysis. Acta Oecol. 2011, 37, 422-432. [CrossRef]

47. Uetz, G.W. Habitat structure and spider foraging. In Habitat Structure: The Physical Arrangements of Objects in Space; Bell, S.S., McCoy, E.D., Mushinsky, H.R., Eds.; Springer: Dordrecht, The Netherlands, 1991; pp. 325-348.

48. Almquist, S. Thermal tolerances and preferences of some dune-living spiders. Oikos 1970, 21, 230-235. [CrossRef]

49. Lowrie, D.C. The ecological succession of spiders of the Chicago Area Dunes. Ecology 1948, 29, 334-351. [CrossRef]

50. Almquist, S. Spider associations in coastal sand dunes. Oikos 1973, 24, 444-457. [CrossRef]

51. MacArthur, R.H.; Wilson, E.O. The Theory of Island Biogeography; Princeton University Press: Princeton, NJ, USA, 1967.

52. Whittaker, R.J.; Triantis, K.A.; Ladle, R.J. A general dynamic theory of oceanic island biogeography. J. Biogeogr. 2008, 35, 977-994. [CrossRef]

53. Thaman, R.R. Atolls-The "biodiversity cool spots" vs "hot spots": A critical new focus for research and conservation. Micronesica 2008, 40, 33-61.

54. Kench, P.S.; McLean, R.F.; Nichol, S.L. New model of reef-island evolution: Maldives, Indian Ocean. Geology 2005, 33, 145-148. [CrossRef]

55. Kench, P.S.; Ford, M.R.; Owen, S.D. Patterns of island change and persistence offer alternate adaptation pathways for atoll nations. Nat. Commun. 2018, 9, 605. [CrossRef] [PubMed]

56. Delcourt, P.A.; Delcourt, H.R. Ecotone dynamics in space and time. In Landscape Boundaries; Hansen, A.J., di Castri, F., Eds.; Springer: Berlin/Heidelberg, Germany, 1992; pp. 19-54.

57. Losos, J.B.; Ricklefs, R.E. Adaptation and diversification on islands. Nature 2009, 457, 830-836. [CrossRef] [PubMed]

58. Barboza, F.R.; Defeo, O. Global diversity patterns in sandy beach macrofauna: A biogeographic analysis. Sci. Rep. 2015, 5, 14515. [CrossRef]

59. Martínez, M.L.; Intralawan, A.; Vázquez, G.; Pérez-Maqueo, O.; Sutton, P.; Landgrave, R. The coasts of our world: Ecological, economic and social importance. Ecol. Econ. 2007, 63, 254-272. [CrossRef] 